\title{
OPTIMALISASI MEKANISME TEKNIS MELALUI PEDOMAN PENGELOLAAN ASET PEMERINTAH KOTA GORONTALO
}

\author{
TECHNICAL MECHANISM OPTIMIZATION THROUGH THE \\ GOVERNMENT ASSET MANAGEMENT GUIDELINES OF GORONTALO \\ CITY
}

\author{
Nuzlan Botutihe ${ }^{1)}$ dan Lukfiah I. Radjak ${ }^{2)}$ \\ ${ }^{1,2)}$ Universitas Muhammadiyah Gorontalo \\ Jl. Prof. Dr. H. Mansoer Pateda No.Desa, Pentadio Tim., Telaga Biru, Kota Gorontalo, \\ Gorontalo 96181 \\ e-mail :lukfiahrdjak@umgo.ac.id
}

\begin{abstract}
ABSTRAK
Penelitian ini bertujuan untuk mengetahui optimalisasi mekanisme teknis melalui pedoman pengelolaan aset Pemerintah yang sesuai dengan Peraturan daerah Kota Gorontalo Nomor 12 Tahun 2016 tentang Pengelolaan Barang Milik Daerah. Jenis penelitian yang digunakan adalah penelitian kualitatif dengan Pendekatan penelitian yaitu studi kasus kemudian sumber informasi dalam penelitian ini dipilih secara purposive. Data diperoleh melalui observasi, wawancara terbuka, dan studi dokumentasi. Hasil penelitian ini menunjukkan bahwa pelaksanaannya mekanisme pengelolaan barang Pemerintah Daerah Gorontalo berjalan sesuai pedoman meskipun ditemukan bahwa fungsi pengawasan dan pengendalian belum berjalan optimal, hal ini disebabkan karena SKPD belum memiliki pejabat pengurus barang. Disisi lain keberadaan pejabat pengurus barang sangat penting. Pejabat pengurus barang tersebut dibuat secara berjenjang mulai dari Kantor Dinas, Unit Pelaksana Teknis Dinas dan unit pengguna barang seperti sekolah. Pejabat pengurus barang inilah yang akan membuat Laporan Barang Pengguna Semesteran (LBPS). Selain itu, pengurus barang juga wajib membuat Laporan Barang Pengguna Tahunan (LBPT).
\end{abstract}

Kata Kunci: Makanisme Teknis, Pengelolaan Aset, Barang Milik Daerah.

\begin{abstract}
This study aims to determine the optimization of technical mechanisms through guidelines for the management of Government assets in accordance with Gorontalo City Regional Regulation Number 12 of 2016 concerning Regional Property Management. This type of research is qualitative research with a research approach, namely case studies and then the sources of information in this study were selected purposively. Data obtained through observation, open interviews, and documentation study. The results of this study indicate that the implementation of the Gorontalo Regional Government's goods management mechanism runs according to the guidelines, although it is found that the supervisory and control functions are not yet running optimally, this is because the SKPD does not yet have goods management officers. On the other hand, the existence of goods management officers is very important. The officer for managing the goods is made in stages starting from the Service Office, the Technical Implementing Unit for the Service and the goods user unit such as schools. It is this goods management officer who will make a Semester User Property Report (LBPS). In addition, the goods manager is also required to make an Annual User Goods Report (LBPT).
\end{abstract}

Keywords: Technical Mechanism, Asset Management, Regional Property 


\section{SEGMEN Jurnal Manajemen dan Bisnis}

Volume 17 No 1 Januari 2021

p-ISSN: 0216-938X e-ISSN: 2684-8414

\section{PENDAHULUAN}

Pengelolaan aset daerah berjalan dengan baik meskipun masih belum berorientasi pada daya guna dan hasil guna yang maksimal, sehingga diperlukan peraturan-peraturan sebagai pedoman dalam pelaksanaan pengelolaan aset daerah (Tukunang, 2016). Selama ini pengelolaan barang inventaris daerah dilaksanakan atas dasar ketentuan Peraturan Pemerintah Nomor 27 Tahun 2014 tentang Pengelolaan Barang Milik Negara/Daerah. Pengelolaan barang milik daerah (aset tetap) membawa efek signifikan terhadap kesempurnaan penyajian neraca daerah (Kolinug et al, 2015).

Masalah utama pemerintah daerah dalam pengelolaan aset daerah (municipal asset management) adalah ketidaktertiban administrasi dalam pengendalian inventarisasi asset, pengedalian dan pemanfaatan aset (Pauweni et al, 2017). Padahal, inventarisasi aset merupakan jantung di dalam siklus pengelolaan aset. Kondisi ini jelas menyebabkan pemerintah daerah mengalami kesulitan untuk mengetahui secara pasti seberapa besar aset yang dimiliki, aset-aset mana saja yang telah dikuasai atau bahkan yang sebenarnya berpotensi dan memiliki peluang investasi tinggi (Yosinta, 2018).

Pemanfaatan aset properti hanya dapat dioptimalkan apabila penilaian terhadap properti daerah secara keseluruhan sudah dipenuhi (Aira, 2015). Pemilihan metode pemanfaatan aset hendaknya didasarkan pada visi dan misi daerah serta metode yang paling memberikan dampak rentetan terbesar terhadap pertumbuhan ekonomi daerah (Runiawati, 2017). Penilaian terhadap properti tidak dapat dilakukan secara sembarangan tetapi harus melalui perhitungan dan analisis secara profesional dengan pertanggungjawaban nilai yang wajar dan marketable, sehingga hasil yang diharapkan dari penilaian properti tersebut mempunyai nilai yang akurat hal ini dapat disesuaikan dengan gaya manajemen aset (Sharpe, 1992).

Untuk mengatasi masalah-masalah pengelolaan aset perlu didorong reformasi manajemen aset yaitu suatu kerangka kerja, sehingga perubahan yang dilakukan dapat mencapai tujuannya (Qiangui,1996; Kaganova \& Nayyar-Stone, 2000; Grubišić et al, 2008). Berdasarkan pengalaman dari empat Negara yang menjadi survey Kaganova (2006), yaitu Australia, Kanada, Selandia Baru dan Prancis, yang telah melakukan reformasi di bidang manajemen aset publik, dilakukan bahwa ada tujuh faktor kunci yang menentukan keberhasilan pelaksanaan reformasi manajemen aset yaitu: kebijakan publik yang jelas, Pengakuan atas biaya kepemilikan aset tetap dan penggunaannya, Sistem Informasi, Mekanisme akuntabilitas, Desentralisasi tanggung jawab manajemen, Inisiatif untuk privatisasi dan Sistem akuntansi (Hariyono, 2007).

Aspek yang ditelusuri pada penelitian ini adalah kinerja pengelolaan aset Pemerintah Kota Gorontalo dilatarbelakangi oleh serangkaian permasalahan yang muncul. Permasalahan dimaksud antara lain: praktik penyimpangan atau penyalahgunaan aset; buruknya pencatatan/inventarisasi aset (belum tersedianya data base aset); pengambilan kebijakan yang tidak tepat sehingga pengelolaan terhadap suatu aset belum mampu memberi kontribusi keuntungan bagi masyarakat secara optimal, hal ini disebabkan perencanaan dan penganggaran aset tidak didasari pada prinsip highest and best use (penggunaan aset berdasarkan kegunaan terbaik dan memberi manfaat yang tertinggi); aset belum 


\section{SEGMEN Jurnal Manajemen dan Bisnis}

Volume 17 No 1 Januari 2021

p-ISSN: 0216-938X e-ISSN: 2684-8414

termanfaatkan secara optimal; dan rendahnya kapabilitas maupun profesionalisme sumber daya aparatur (pengelola aset daerah); serta praktek pengelolaan aset yang belum optimal. Oleh karena itu penelitian ini bertujuan untuk mengetahui Optimalisasi Mekanisme Teknis melalui pedoman pengelolaan aset Pemerintah yang sesuai dengan Peraturan daerah Gorontalo Nomor 12 Tahun 2016 tentang Pengelolaan Barang Milik Daerah.

\section{METODE PENELITIAN}

Jenis penelitian yang digunakan adalah penelitian kualitatif dengan Pendekatan penelitian yang digunakan, yakni studi kasus. Melalui studi kasus diharapkan pendekatan yang dihasilkan pada Kabupaten/Kota lokasi penelitian akan dapat direpresentasikan atau digunakan untuk menggambarkan dan menjelaskan kasuskasus serupa di lokasi lain (Denzin \& Lincoln, 1994). Sumber informasi dalam penelitian ini dipilih secara purposive (sengaja), yang dianggap memiliki informasi tentang masalah penelitian. Adapun sumber informasi data primer diperoleh dari informan yang terdiri dari 10 (sepuluh) orang dari unsur birokrat, dan 1 (satu) orang staf/pegawai pengelola aset (pihak ketiga). Sementara informan dari unsur pengguna aset (user) adalah berjumlah 16 (enam belas) orang. Mengingat penelitian kualitatif maka metode pengumpulan data yang dipilih untuk mendapatkan informasi adalah observasi, wawancara terbuka, dan studi dokumentasi.

\section{HASIL DAN PEMBAHASAN}

Pedoman teknis pengelolaan barang milik daerah, ini dijadikan acuan bagi Pemerintah Kota Gorontalo dalam melaksanakan Pengelolaan barang milik daerah (Aset daerah). Tujuan yang diharapkan adalah untuk mencapai tertib administrasi pengelolaan barang milik daerah secara berdaya guna dan berhasil guna, serta untuk memberi kepastian hukum dalam pengelolaannya sesuai Peraturan daerah Kota Gorontalo No.12 Tahun 2016.

Walikota sebagai pemegang

kekuasaan Pejabat pengelola barang berwenang dan bertanggung jawab atas pembinaan dan pelaksanaan pengelolaan barang. Walikota berwewenang; menetapkan kebijakan pengelolaan barang; menetapkan penggunaan, pemanfaatan atau pemindahtanganan tanah dan bangunan; menetapkan kebijakan pengamanan barang; mengajukan usul penghapusan dan atau pemindahtanganan barang yang memerlukan persetujuan Dewan Perwakilan Rakyat Daerah (DPRD) menyetujui usul pemindahtanganan dan penghapusan barang sesuai batas kewenangannya, dan juga menyutujui usul pemanfaatan barang selain tanah dan/atau bangunan.

Dalam melaksanakan kewenangannya, Walikota sebagai pemegang kekuasaan pengelolaan barang dapat dibantu oleh Sekretaris Daerah selaku pengelola; yakni pejabat yang berwenang dan bertanggung jawab melakukan koordinasi pengelolaan barang milik daerah. Memiliki tanggung jawab dan berwenang: Menetapkan pejabat yang mengurus dan menyimpan barang; Meneliti dan menyetujui rencana kebutuhan barang; Meneliti dan menyetujui rencana kebutuhan pemeliharaan/perawatan barang; Mengatur pelaksanaan pemanfaatan, penghapusan dan pemindahtanganan barang yang telah disetujui oleh Walikota; Melakukan koordinasi dalam pelaksanaan inventarisasi barang; serta Melakukan 


\section{SEGMEN Jurnal Manajemen dan Bisnis}

Volume 17 No 1 Januari 2021

p-ISSN: 0216-938X e-ISSN: 2684-8414

pengawasan dan pengendalian atas pengelolaan barang.

Untuk lebih detailnya pembahasan tentang mekanisme teknis pengelolaan aset pemerintah Kota Gorontalo, penulis akan menguraikan tahapan-tahapan yang mengatur pengelolaan aset Pemerintah Kota Gorontalo berdasarkan Perda Nomor 12 Tahun 2016 sebagai berikut:

\section{Perencanaan Kebutuhan dan Penganggaran}

Tahapan pertama dalam alur/mekanisme pengelolaan aset Pemerintah Kota Gorontalo adalah Perencanaan kebutuhan dan penganggaran. Sebagaimana yang tertuang dalam Perda Kota Gorontalo Nomor 12 Tahun 2016, mengatur hal-hal sebagai berikut: Perencanaan kebutuhan barang dan perencanaan kebutuhan pemeliharaan barang disusun dalam Rencana Kerja dan Anggaran (RKA) di masing-masing SKPD setelah memperhatikan ketersediaan barang yang ada, yang berpedoman pada standarisasi sarana dan prasarana kerja pemerintahan daerah yang ditetapkan dengan Peraturan Walikota, dan standar harga yang ditetapkan dengan Keputusan Walikota. Rencana kebutuhan dan pemeliharaan barang dari masing-masing SKPD inilah sebagai bahan penyusunan Rencana Anggaran Pendapatan Belanja Daerah (APBD). Selanjutnya, pengelola (Sekda) bersama pengguna (SKPD) membahas usul rencana kebutuhan dan pemeliharaan barang dari masing-masing SKPD tersebut dengan memperhatikan data barang pengguna dan/atau pengelola.

Setelah APBD ditetapkan, pembantu pengelola (Kabag Perlengkapan) menyusun Daftar Kebutuhan dan Pemeliharaan Barang sebagai dasar pelaksanaan pengadaan dan pemeliharaan barang, untuk kemudian ditetapkan dengan Keputusan walikota. Perlu ditekankan, bahwa Kabag Perlengkapan sesuai tugas dan fungsinya duduk sebagai Tim Pemerintah Kota Gorontalo dalam penyusunan Rancangan APBD.

\section{Pengadaan}

Tahap berikutnya setelah perencanaan kebutuhan dan penganggaran, yaitu pengadaan barang Pemerintah Kota Gorontalo dilaksanakan oleh panitia pengadaan barang pemerintah kota Gorontalo yang ditetapkan dengan keputusan Walikota Gorontalo. Dalam pembentukan panitia pengadaan barang ini, Walikota Gorontalo dapat melimpahkan kewenangan kepada SKPD untuk membentuknya atau menunjuk pejabat pengadaan barang. Sementara itu, Pengguna dalam melaksanakan pengadaan, diwajibkan membuat laporan pengadaan barang kepada Walikota Gorontalo melalui pengelola (Sekda). Kemudian dalam rangka pengawasan, realisasi pengadaan barang dilakukan pemeriksaan oleh Panitia Pemeriksaan barang yang juga pembentukannya melalui pelimpahan kewenangan Walikota Gorontalo kepada SKPD.

\section{Penerimaan dan Penyaluran}

Hasil pengadaan barang diterima oleh penyimpan barang. Barang berupa tanah yang diperoleh dari pihak ketiga yang terdiri dari prasarana lingkungan, utilitas umum dan fasilitas sosial yang diterima oleh pemerintah kota Gorontalo dalam berita acara, untuk kemudian segera ditindaklanjuti dengan balik nama atas nama pemerintah kota Gorontalo dan dicatat dalam Buku Daftar Inventaris Daerah (BDID). Sementara itu, hasil pengadaan barang tidak bergerak diterima oleh Kepala SKPD, kemudian kepala SKPD 


\section{SEGMEN Jurnal Manajemen dan Bisnis}

Volume 17 No 1 Januari 2021

p-ISSN: 0216-938X e-ISSN: 2684-8414

melaporkan kepada Walikota Gorontalo melalui Kabag Perlengkapan untuk ditetapkan penggunaannya. Penerimaan barang sebagaimana dimaksud tersebut dilakukan setelah sebelumnya dilakukan pemeriksaan oleh Panitia Pemeriksa Barang Daerah, dengan membuat Berita Acara Pemeriksaan, serta Kabag Perlengkapan melakukan pencatatan barang tersebut.

\section{Penggunaan}

Status penggunaan barang ditetapkan untuk penyelenggaraan tugas pokok dan fungsi SKPD, dan dapat dioperasikan oleh pihak lain dalam rangka mendukung pelayanan umum sesuai tugas pokok dan fungsi SKPD bersangkutan. Status penggunaan barang ini ditetapkan dengan keputusan Walikota Gorontalo dan diatur dengan cara; pengguna melaporkan barang yang diterima kepada pengelola disertai usul penggunaannya.

Untuk kategori aset tanah dan bangunan, penetapan status penggunaan dilakukan dengan ketentuan bahwa tanah dan/atau bangunan digunakan untuk kepentingan penyelenggaraan tugas pokok dan fungsi penggunan/dan atau kuasa penguna. Pengguna atau kuasa pengguna wajib menyerahkan tanah/dan atau bangunan termasuk barang inventaris lainnya yang tidak digunakan untuk kepentingan penyelenggaraan tugas pokok dan fungsi pengguna dan/atau kuasa pengguna kepada Walikota melalui pengelola dengan Berita Acara. Pengguna yang tidak menyerahkan tanah dan/atau bangunan sebagaimana dimaksud, dikenakan sanksi berupa pembekuan dana pemeliharaan tanah dan/atau bangunan dimaksud, dan dilaporkan kepada aparat pengawasan Pemerintah Kota Gorontalo untuk ditindaklanjuti dan dilaporkan hasilnya kepada Walikota Gorontalo. Selanjutnya, tanah dan/atau bangunan yang tidak digunakan sesuai tugas pokok dan fungsinya, dapat dicabut penetapan status penggunaannya dan dapat dialihkan kepada SKPD lain.

Dalam temuan penelitian, mekanisme penggunaan dalam pelaksanaannya sering terjadi penyimpangan atau pengabaian terhadap prosedur ini. Seringkali Pengguna (SKPD) lalai dari menyerahkan tanah dan atau bangunan termasuk barang inventaris lainnya yang tidak digunakan. Hal tersebut berimplikasi terhadap munculnya idle asset, yaitu aset yang tidak termanfaatkan atau tidak memberi manfaat bagi Pemerintah Kota Gorontalo (selaku pemilik/pengelola aset). Terdapatnya idle asset dalam pengelolaan aset daerah merupakan sebuah indikasi bahwa pengelolaan aset belum berjalan secara optimal, dan bisa saja menimbulkan masalah bagi pemerintah Kota Gorontalo.

\section{Penatausahaan}

Tahapan pada penatausahaan ini terdiri atas beberapa tahapan, yaitu pembukuan, baik Pengguna ataupun Kuasa Pengguna melakukan pencatatan dan pendaftaran barang ke dalam Daftar Barang yang dimuat pada Kartu Inventaris Barang. Oleh Pembantu Pengelola (Kabag Perlengkapan) melakukan rekapitulasi atas pencatatan dan pendaftaran barang melalui Daftar Barang yang dilaporkan oleh para SKPD yang dalam hal ini selaku Pengguna Barang.

Setiap dokumen kepemilikan barang, yaitu selain tanah dan bangunan harus disimpan dalam brankas, dan dalam hal ini dilakukan oleh Penguna/Kuasa Pengguna. Sementara itu, Pengelola (Sekda) wajib mengetahui dan/atau menyimpan seluruh 


\section{SEGMEN Jurnal Manajemen dan Bisnis}

Volume 17 No 1 Januari 2021

p-ISSN: 0216-938X e-ISSN: 2684-8414

dokumen kepemilikan tanah atau bangunan milik Pemerintah Kota Gorontalo. Dalam hal tanah yang belum mempunyai dokumen kepemilikan, maka Pengelola wajib mengadakan dokumen kepemilikan sesuai peraturan yang berlaku.

Selanjutnya inventarisasi, pengelola dan pengguna menyelenggarakan sensus barang setiap 5 (lima) tahun sekali guna menyusun Buku Inventaris dan Buku Induk Inventaris beserta rekapitulasi barang milik Pemerintah Kota Gorontalo. Pengelola bertanggung jawab atas pelaksanaan sensus barang ini, sementara Pengguna yang melaksanakan dan menyampaikan hasil sensus kepada Pengelola paling lambat 3 (tiga) bulan setelah selesainya sensus, untuk kemudian diketahui oleh Walikota Gorontalo dan ditetapkan dengan keputusan Walikota. Bagi Pembantu Pengelola (Kabag Perlengkapan) bertugas untuk menghimpun hasil Inventarisasi barang milik daerah tersebut. Kemudian Pelaporan, dalam hal ini, Pengguna menyusun laporan barang semesteran dan tahunan. Laporan tersebut disampaikan kepada Walikota Gorontalo melalui Pengelola (Sekda) atau Pembantu Pengelola (Kabag Perlengkapan). Pada tahapan Pelaporan ini, Pembantu Pengelola juga bertugas menghimpun berbagai laporan dari Pengguna, yang kemudian disebut laporan Barang Milik Daerah (LBMD). LBMD inilah yang kemudian digunakan sebagai bahan untuk menyusun neraca Pemerintah Kota Gorontalo. Untuk memudahkan proses pendaftaran, pencatatan, dan pelaporan barang secara akurat dan cepat dipergunakan aplikasi Sistem Informasi yang terkoneksikan dengan aplikasi BPKP.

\section{Pemanfaatan}

Pemanfaatan barang didasarkan atas pertimbangan teknis dengan memperhatikan kepentingan negara/daerah dan kepentingan umum. Setiap pemanfaatan tanah dan/atau bangunan, maupun selainnya yang dipergunakan untuk menunjang penyelenggaraan tugas pokok dan fungsi SKPD (Pengguna), dilaksanakan oleh Pengguna setelah mendapatkan persetujuan dari Pengelola (Sekretaris Daerah). Adapun tanah dan/atau bangunan yang tidak dipergunakan dalam menunjang tugas SKPD, pemanfaatannya diambil alih atau dilaksanakan oleh Pengelola setelah mendapat persetujuan Walikota Gorontalo.

Pemanfaatan barang milik Pemerintah Kota Gorontalo, dalam implementasinya dikenal dengan beberapa model/jenis pemanfaatan, seperti: Sewa, Pinjam Pakai, Kerjasama Pemanfaatan, dan Bangun Gunah serah serta Bangun Serah Guna. Kasubid Penata Usahaan dan Pengawasan aset (HI), mengungkapkan, dalam rangka mengoptimalkan pemanfaatan asetnya, Pemerintah Kota Gorontalo menempuh langkah kerjasama pemanfaatan aset-aset daerah.

\section{Pengamanan dan Pemeliharaan}

Dalam hal pengamanan, Pengelola, Pengguna dan/atau Kuasa Pengguna, wajib melakukan pengamanan barang yang berada dalam penguasaannya. Pengamanan barang dimaksud meliputi: (1) pengamanan administrasi; meliputi kegiatan pembukuan, Inventarisasi, pelaporan, dan penyimpanan dokumen kepemilikan; (2) pengamanan fisik untuk mencegah terjadinya penurunan fungsi barang, penurunan jumlah barang dan hilangnya barang; (3) pengaman fisik untuk tanah dan bangunan dilakukan dengan cara 


\section{SEGMEN Jurnal Manajemen dan Bisnis}

Volume 17 No 1 Januari 2021

p-ISSN: 0216-938X e-ISSN: 2684-8414

pemagaran dan pemasangan tanda batas, selain tanah dan bangunan dilakukan dengan cara penyimpanan dan pemeliharaan; (4) pengamanan hukum antara lain meliputi kegiatan melengkapi bukti status kepemilikan; serta (5) pengamanan fisik bangunan dilakukan rehabilitasi baik itu ringan, sedang, berat maupun rehabilitasi total.

Dalam hal memantau kinerja masingmasing SKPD (Pengguna), Bagian Perlengkapan (Pembantu Pengelola) berperan untuk mengawasi dan mengecek sejauh mana tugas dan fungsi pengelolaan aset di SKPD telah berlangsung. Tentu hal ini mengacu pada standar jadwal yang seharusnya berlangsung. Seperti pada dokumen-dokumen pelaporan yang harus diserahkan/dilaporkan dalam limit waktu tertentu. Tentu yang diharapkan adalah agar SKPD dalam melaksanakan pekerjaannya tidak terkesan berlangsung apa adanya, namun menekankan kualitas pada pekerjaan, sehingga kinerja yang diharapkan tidak sekedar formalitas maupun rutinitas, namun lebih jauh kepada kualitas yang bermuara pada efisiensi dan efektifitas kinerja pengelolaan aset. Sementara itu, langkah Pemeliharaan menjadi tanggung jawab Pembantu Pengelola, Pengguna dan/atau Kuasa Pengguna. Penanggung jawab sebagaimana dimaksud wajib membuat Daftar Hasil Pemeliharaan Barang dan melaporkan kepada Pengelola secara berkala.

\section{Penilaian}

Penilaian barang milik Pemerintah Kota Gorontalo dilakukan dalam rangka penyusunan neraca. Dan dijadikan sebagai dasar pengambilan keputusan terhadap langkah pemanfaatan dan pemindah tanganan barang milik Pemerintah Kota Gorontalo.
Penilaian barang dimaksud berpedoman pada Standar Akuntansi Pemerintahan (SAP).

Penilaian barang berupa tanah dan bangunan dilaksanakan untuk mendapatkan nilai wajar dengan estimasi terendah menggunakan Nilai Jual Objek pajak (NJOP). Penilaian dilakukan oleh Tim yang ditetapkan Walikota Gorontalo dan dapat melibatkan penilai independen yang bersertifikat di bidang penilaian aset.

Sebagaimana diamanatkan dalam Peraturan Pemerintah Nomor 12 Tahun 2016, dan Peraturan Menteri Dalam Negeri Nomor 17 Tahun 2007 tentang Pedoman Teknis Pengelolaan Barang Milik Daerah, bahwa dalam rangka menyusun neraca pemerintah perlu diketahui berapa jumlah aset negara/daerah sekaligus nilai dari aset tersebut. Untuk diketahui nilainya maka barang milik negara/daerah secara periodik harus dilakukan penilaian, sehingga dapat diketahui nilai barang/aset secara tepat. Pengelola Barang diharuskan melakukan inventarisasi sekaligus penilaian Barang Milik Negara/Daerah berupa tanah dan/atau bangunan minimal sekali dalam 5 tahun.

\section{Penghapusan dan Pemindahtanganan}

Penghapusan barang dapat ditempuh dalam dua bentuk yaitu penghapusan dari daftar barang pengguna dan/atau kuasa pengguna, dilakukan dalam hal barang dimaksud tidak berada dalam penguasaan pengguna dan/atau kuasa pengguna. Selanjutnya penghapusan dari daftar barang milik daerah, dilakukan dalam hal barang dimaksud sudah beralih kepemilikannya, terjadi pemusnahan atau sebab-sebab lain seperti rusak karena kecelakaan, maupun tidak dapat digunakan karena biaya perbaikan lebih besar dari manfaatnya. 


\section{SEGMEN Jurnal Manajemen dan Bisnis}

Volume 17 No 1 Januari 2021

p-ISSN: 0216-938X e-ISSN: 2684-8414

Penghapusan barang dengan tindak lanjut pemusnahan, dilakukan apabila barang dimaksud tidak dapat lagi digunakan, tidak dapat dimanfaatkan dan tidak dapat dipindahtangankan, ataupun alasan lain sesuai ketentuan yang berlaku. Sementara itu, barang yang dihapus tapi masih mempunyai nilai ekonomis, dapat dilakukan melalui pelelangan ataupun disumbangkan/dihibahkan kepada pihak lain.

\section{Pembinaan, Pengendalian, dan}

\section{Pengawasan}

Walikota Gorontalo melakukan pembinaan pengelolaan barang, dibantu oleh Sekretaris Daerah Kota Gorontalo selaku pengelola melakukan pengendalian pengelolaan barang. Sementara itu, bagi pengguna melakukan pemantauan dan penerbitan terhadap penggunaan, pemanfaatan, pemindahtanganan, penatausahaan, pemeliharaan, dan pengamanan barang yang berada di bawah penguasaannya.

Pengguna dan kuasa pengguna barang dapat meminta aparat pengawas fungsional untuk melakukan audit sebagai tindak lanjut dari hasil pemantauan. Dan hasil audit tersebut ditindak lanjuti oleh Pengguna dan kuasa pengguna sesuai ketentuan perundangundangan.

Pengelola berwenang melakukan pemantauan dan investigasi atas pelaksanaan penggunaan, pemanfaataan, dan pemindahtanganan barang dalam rangka penerbitan penggunaan, pemanfaatan, dan pemindahtanganan barang. Untuk keperluan pemantauan dan investigasi, pengelola dapat meminta aparat pengawas fungsional untuk melakukan audit atas pelaksanaan penggunaan, pemanfaatan dan pemindahtanganan barang.

\section{Pemerintah}

Kota

Gorontalo mewajibkan setiap SKPD memiliki pejabat pengurus barang. Pejabat pengurus barang tersebut dibuat secara berjenjang mulai dari Kantor Dinas, Unit Pelaksana Teknis Dinas dan unit pengguna barang seperti sekolah. Pejabat pengurus barang inilah yang akan membuat Laporan Barang Pengguna Semesteran (LBPS). Selain itu, pengurus barang juga wajib membuat Laporan Barang Pengguna Tahunan (LBPT). Laporan ini bertujuan mengetahui barang yang bertambah dan berkurang dari tahun sebelumnya. Selain itu, pejabat pengurus barang juga harus membuat laporan lima tahunan. Laporan tersebut dibuat untuk mengetahui mutasi barang termasuk tanah selama lima tahun. Dalam mengemban tugas tersebut, Pejabat pengurus barang tersebut wajib diberikan insentif sesuai kemampuan Pemerintah Kota Gorontalo. Apabila pejabat pengurus barang tersebut tidak melaksanakan tugasnya dengan baik maka akan diberikan sanksi yaitu ditegur secara tertulis dan tidak memperoleh honor.

\section{KESIMPULAN}

Mekanisme teknis pengelolaan asset Pemerintah Kota Gorontalo berpatokan pada regulasi pengelolaan barang mirik daerah (BMD) yang diatur dalam Pemerintah Daerah Kota Gorontalo Nomor 12 Tahun 2016, tentang Pengelolaan Barang Milik Daerah, yang merupakan mekanisme teknis pengelolaan asset daerah. Dalam pelaksanaannya mekanisme pengelolaan barang Pemerintah Daerah Gorontalo telah berjalan sesuai pedoman namun fungsi pengawasan dan pengendalian belum berjalan optimal, hal ini disebabkan karena SKPD belum memiliki pejabat pengurus barang. Disisi lain keberadaan pejabat pengurus barang sangat penting. Pejabat pengurus 


\section{SEGMEN Jurnal Manajemen dan Bisnis}

Volume 17 No 1 Januari 2021

p-ISSN: 0216-938X e-ISSN: 2684-8414

barang tersebut dibuat secara berjenjang mulai dari Kantor Dinas, Unit Pelaksana Teknis Dinas dan unit pengguna barang seperti sekolah. Pejabat pengurus barang inilah yang akan membuat Laporan Barang Pengguna Semesteran (LBPS). Selain itu, pengurus barang juga wajib membuat Laporan Barang Pengguna Tahunan (LBPT). Apabila pejabat pengurus barang tidak melaksanakan tugas tersebut dengan baik maka akan diberikan sanksi yaitu ditegur secara tertulis dan tidak memperoleh honor.

\section{DAFTAR PUSTAKA}

Aira, A. (2015). Peran Manajemen Aset Dalam Pembangunan Daerah. Kutubkhanah, 17(1), 21-39.

Denzin, N. K., \& Lincoln, Y. S. (1994). Handbook of qualitative research. Sage publications, inc.

Grubišić, M., Nušinović, M., \& Roje, G. (2008). From accountable government to public asset management reform and welfare. Privredna kretanja i ekonomska politika, 18(117), 58-117.

Hariyono, Arik.(2007). Prinsip \& Teknik Manajemen Kekayaan Negara. Jakarta: Kementerian Keuangan Republik Indonesia Badan Pendidikan dan Pelatihan Keuangan Umum.

Kaganova, O. (2006). Managing government property assets: international experiences. The Urban Insitute.

Kaganova, O., \& Nayyar-Stone, R. (2000). Municipal real property asset management: An overview of world experience, trends and financial implications. Journal of Real estate portfolio management, 6(4), 307-326.

Kolinug, M. S., Ilat, V. I., \& Pinatik, S. (2015). Analisis Pengelolaan Aset Tetap
Pada Dinas Pendapatan Pengelolaan Keuangan dan Aset Daerah Kota Tomohon. Jurnal EMBA: Jurnal Riset Ekonomi, Manajemen, Bisnis dan Akuntansi, 3(1).

Pauweni, S., Karamoy, H., \& Gamaliel, H. (2017). Pengaruh Inventarisasi, Legal Audit, Penilaian dan Kondisi Aset terhadap Optimalisasi Pemanfaatan Aset pada Pemerintah Daerah Kabupaten Bone Bolango. Jurnal Riset Akuntansi Dan Auditing"Goodwill", 8(2).

Qiangui, J. (1996). State asset management reform: clarified property rights and responsibilities. World Bank Discussion Papers, 91-100.

Runiawati, N. (2017). Pemanfaatan Barang Milik Daerah (Suatu pendekatan teoritis dan praktis dalam menentukan metode pemanfaatan aset). Jurnal Manajemen Pelayanan Publik, 1(1), 45-58.

Sharpe, W. F. (1992). Asset allocation: Management style and performance measurement. Journal of portfolio Management, 18(2), 7-19.

Tukunang, S. C. (2016). Manajemen Aset Daerah Pada Dinas Pendapatan Pengelolaan Keuangan Dan Aset Daerah Kabupaten Kepulauan Siau, Tagulandang, Biaro. Jurnal EMBA: Jurnal Riset Ekonomi, Manajemen, Bisnis dan Akuntansi, 4(2).

Yosinta, K. N. (2018). Pengelolaan Aset Tanah Pemerintah Kabupaten Purbalingga (Doctoral dissertation, Faculty of Social and Political Sciences). 